\title{
Parasitic density and ornithochoric potential of wild birds: preliminary results of a research and extension project carried out in a reforestation area at IFRJ Campus, Pinheiral, Rio de Janeiro, Brazil
}

Densidade parasitária e potencial ornitocórico de aves silvestres: resultados preliminares de um projeto de pesquisa e extensão realizado em área de reflorestamento no Campus IFRJ, Pinheiral, Rio de Janeiro, Brasil

\section{Sérgio Thode-Filho'(i), Heider Alves Franco"II),}

Emanuele Nunes de Lima Figueiredo Jorge ${ }^{\prime \prime \prime}(\mathbb{D}$, Mariana de Souza Oliveira'(i), Jhon Lennon Genovez-OliveiralV(D), Lucas de Assis Silva Andrade ${ }^{\mathrm{IV}}$ (i),

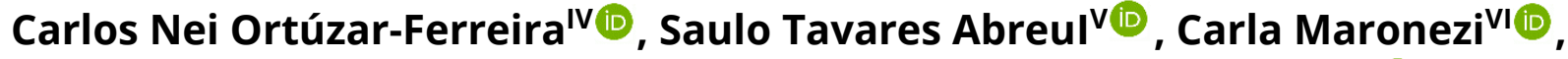
Águida Aparecida de OliveiraVIII), Viviane Moreira de LimavilI(I), Ildemar Ferreira ${ }^{\mathrm{VIII}} \mathbb{1}^{\circ}$, Bruno Pereira Berto ${ }^{\mathrm{VIII}}$

\footnotetext{
I,Instituto Federal de Educação, Ciência e Tecnologia do Rio de Janeiro, Duque de Caxias, RJ, Brasil " Universidade Federal Rural do Rio de Janeiro, Programa de Pós-graduação em Ciência, Tecnologia e Inovação em Agropecuária, Seropédica, RJ, Brasil

III Instituto Federal de Educação, Ciência e Tecnologia do Rio de Janeiro, Pinheiral, Rio de Janeiro, Brasil

Iv Programa de Pós-graduação em Biologia Animal, Instituto de Ciências Biológicas e da Saúde, Universidade Federal Rural do Rio de Janeiro, Seropédica, RJ, Brasil

vUniversidade Federal Rural do Rio de Janeiro, Curso em Medicina Veterinária, Seropédica, RJ, Brasil VIUniversidade Federal Rural do Rio de Janeiro, Curso, Seropédica, RJ, Brasil

VIICentro Universitário de Barra Mansa, Curso em Medicina Veterinária, Barra Mansa, RJ, Brasil VIII Universidade Federal Rural do Rio de Janeiro, Departamento de Biologia Animal, , Seropédica, RJ, Brasil
}

\begin{abstract}
This publication aims to disseminate to the scientific community and society in general, the project of the same title of this publication that is under development by the collaboration of the Instituto Federal de Educação, Ciência e Tecnologia do Rio de Janeiro (IFRJ) and the Universidade Federal Rural do Rio de
\end{abstract}


Janeiro (UFRRJ). Briefly, this project aims to quantify and identify parasites of the body surface (ectoparasites) and intestinal parasites (enteroparasites) of wild birds, which should be related to their biological and ecological conditions, and to evaluate the dispersal seed process performed by birds (ornithocoria), the viability and development of these seeds and thus establish the degree of importance of ornithocoria in reforestation at the IFRJ campus of Pinheiral, RJ. The project includes the integration of five doctoral professors, a laboratory technician doctor, as well as a postdoctoral student, four doctoral students, one master student, two undergraduate students and four technical high school students. To date, six expeditions have been made in the reforestation area of the Espaço Ecológico Educativo (EEcoE) of the IFRJ campus in Pinheiral, RJ, where a total of 196 wild birds have been captured, evaluated, ringed and recorded at the Centro Nacional de Pesquisa e Conservação de Aves Silvestres (CEMAVE), of which 29 were recaptured for revaluations. Four articles were published on the themes of parasitology and ornithochory in wild birds. Two practical short courses in the area of study were taught in September 2018 and February 2019 to IFRJ students, but open to the scientific community and society at large. Currently the project is not expected to end, since there are plenty of unpublished and relevant results in both the area of parasitology and ornithochory of wild birds.

Keywords: Birds; Parasites; Coccidia; Ornithochoria; Seeds; Atlantic Forest

\section{RESUMO}

A presente publicação tem por objetivo divulgar, à comunidade científica e à sociedade em geral, o projeto de mesmo título desta publicação que está em desenvolvimento em colaboração dos Instituto Federal de Educação, Ciência e Tecnologia do Rio de Janeiro (IFRJ) e Universidade Federal Rural do Rio de Janeiro (UFRRJ). Resumidamente, este projeto objetiva quantificar e identificar parasitas da superfície corporal (ectoparasitas) e parasitas intestinais (enteroparasitas) de aves silvestres, os quais devem estar relacionados às suas condições biológicas e ecológicas, além de avaliar o processo de dispersão de sementes desempenhado pelas aves (ornitocoria), a viabilidade e desenvolvimento destas sementes e, desta forma, estabelecer o grau de importância da ornitocoria no reflorestamento no campus IFRJ de Pinheiral, RJ. O projeto conta com a integração de cinco professores doutores, uma doutora técnica de laboratório, além de um pós-doutorando, quatro doutorandos, um mestrando, dois estudantes de iniciação científica e quatro estudantes de ensino médio-técnico. Até o presente momento, foram realizadas seis expedições na área em reflorestamento do Espaço Ecológico Educativo (EEcoE) do campus IFRJ em Pinheiral, RJ, onde o total de 196 aves silvestres foram capturadas, avaliadas, anilhadas e registradas no Centro Nacional de Pesquisa e Conservação de Aves Silvestres (CEMAVE), das quais 29 foram recapturadas para reavaliações. Quatro artigos foram publicados nos temas de parasitologia e ornitocoria em aves silvestres. Dois minicursos práticos, na área de estudo, foram ministrados em setembro de 2018 e fevereiro de 2019 para alunos do IFRJ, porém aberto para a comunidade científica e sociedade em geral. Atualmente o projeto não tem previsão para término, desde que há abundância de resultados inéditos e relevantes tanto na área de parasitologia, quanto ornitocoria em aves silvestres.

Palavras-chave: Aves; Parasitas; Coccídios; Ornitocoria; Sementes; Mata Atlântica

\section{INTRODUCTION}

The Atlantic Forest is a highly diverse biome and is also one of the most endangered on the planet and, therefore, considered one of the five most 
important biodiversity hotspots (MYERS et al. 2000; CARVALHO et al., 2005). In the state of Rio de Janeiro, it is estimated that the Atlantic Forest originally covered around $98 \%$ of its territory, considering its different forest formations and associated ecosystems, such as mangroves, restingas and altitude fields (IEF, 2007). Currently the original cover is restricted to less than $20 \%$, being quite fragmented and disconnected, represented almost entirely by small scattered forest patches, in hard-to-reach, isolated and impacted areas, surrounded by extensive pasture matrices, monocultures and urban áreas (FUNDAÇÃO SOS MATA ATLÂNTICA, 2002).

The drastic elimination of riparian forests and forest fragmentation, verified in Brazil and accelerated in the last decades, have caused a significant increase of soil erosion processes, damaging the regional hydrology, evident biodiversity reduction and the degradation of huge areas subjected to to these anthropic actions (BARBOSA, 2001). Fragmentation was defined by Lord \& Norton (1990) as a process of disruption in the spatial continuity of natural habitats and which often causes disruption of gene flows between populations present in these habitats. The negative effects of fragmentation on the environment depend on factors such as: shape of the fragment, dominant features in the vicinity, level of degradation of these features, among others (MARTINS et al., 2002). In some of the anthropized environments, the process of natural regeneration can be observed occurring slowly and dependent on factors such as: environmental conditions (climate and slope), type and intensity of disturbance and distance and source of propagules (VENTUROLI et al., 2011). In environments where conditions are favorable, the regeneration process happens more spontaneously, being ordered and predictable through the dynamics of succession of the plant species involved (SILVEIRA; SILVA, 2010).

The municipality of Pinheiral, in the State of Rio de Janeiro, represents the history of the occupation of the region of the Middle Valley of the Paraíba do Sul River, which also covers the municipalities of Barra do Piraí, Barra Mansa, Itatiaia, 
Piraí, Porto Real, Quatis, Resende, Rio Claro, Rio das Flores, Valença and Volta Redonda, where the several cycles of agriculture practiced in an erroneous way, led to the current scenario in the region, where islands of small forest fragments are observed amidst extensive pasture areas and, to a lesser extent scale, subsistence agriculture. The municipality has a single headquarters district, occupying a total area of 76.5 square kilometers, corresponding to $1.2 \%$ of the area of the Middle Paraíba Region.

Forest fragmentation threatens the biodiversity of the Atlantic Forest, since, in addition to direct impacts on fauna, flora and microbiota, indirectly favor the transmission and susceptibility of wild animals to parasites. In this context, arises the importance of the knowledge of the ecology of the wild birds, which are extremely important in the forestation process, besides being bioindicators of environmental impacts (BERTO; LOPES, 2013). In this context, the project presented in this article identified the campus Pinheiral of the Instituto Federal de Educação, Ciência e Tecnologia do Rio de Janeiro (IFRJ-Pinheiral) as a representative locality for the development of this work, since it has diverse environmental conditions, such as preserved, urbanized, cultivated areas and, mainly, in reforestation. In this sense, we can observe the preliminary results of this project, which are the identification and quantification of ecto- and endo-parasites in wild birds related to the capture sites, as well as the role of wild birds in seed dispersal and, consequently, the maintenance of forests and reforestation.

\subsection{Frugivory and ornithochory}

The geographical dispersion of seeds is an essential factor for the maintenance of plant species in nature, a fact that can be seen by the enormous variety of adaptive mechanisms that exist to guarantee the perpetuation of progenies, ranging from physical mechanisms to those dependent on ecological interactions. Thus, the biological weathering can be classified as: Anemochory; autochory; hydrochory; barocchory and zoochory (SARAVY et al., 2003). 
Frugivory corresponds to the alimentary habit of dietary dependence strict or not to the consumption of fruits by the animals, among which the birds assume great importance. These are one of the greatest dispersers of the diaspora, mainly because of the high capacity of displacement and mobility due to the artifice of the flight. This dispersion by birds is called ornithochory (PEREIRA et al., 2014).

The evolutionary irradiation of the angiosperms brought the fruit as great emolument. In this aspect, the established symbiosis is of great ecological gain, since birds help to sustain the gene flow of plant populations and in return, receive a food of high nutritional value (FRANCISCO; GALETTI, 2001). Within this same perspective, the existence of a biological dependence can also expose the fragility with which the systems are configured. Thus, the disappearance of plant or dispersant can strongly impact the ecological balance.

As proposed by Janzen (1970) there is a natural tendency of the density of seeds and seedlings (young plants) to be larger in the vicinity of the parent plant. However, this fact is unfavorable for their survival. This is because agglomeration favors herbivory, dissemination of pathogens or pests and increases interspecific competition. This fact confirms the importance of the dispersion of the seeds, and especially of the ornitochory (BIZERRIL, 2000). In addition, birds exert another vital importance, the breakdown of seed dormancy. There are species of plants, for example, that essentially require the passage through the gastrointestinal tract of the animals to become suitable for germination (ANTONINI, 2007).

\subsection{Parasites of wild birds}

The parasites can affect the morphology, behavior and health of the vertebrate host, even in sub-lethal infections or infestations, exerting important ecological and evolutionary pressure. Therefore, the identification and quantification of the parasites is essential for the understanding of the ecological and evolutionary implications of the parasites in the hosts and consequently in the ecosystem (MASELLO et al., 2006). Birds are host to a large variety of parasites, 
mostly intestinal (MASELLO et al., 2006), which have an elaborate adaptive mode of life within the organism and can cause severe diseases that impact reproduction and survival (MARTÍNEZ-PADILLA; MILLÁN, 2007) and may affect various aspects of host life (BOUGHTON, 1937; NORRIS; EVANS, 2000; DOLNIK et al., 2010). Birds have antiparasitic, physiological or immune defenses against parasites. Some factors influencing the intensity of infection in nature include genetics, immunological defense, season of the year, migration, age, size, sex, and hormonal status (MASELLO et al., 2006).

Coccidiosis is considered an important cause of enteritis and death in birds of all species. It is a disease caused by protozoan coccidia mainly from the Eimeriidae family (FREITAS et al., 2002). The coccidia are mostly intestinal parasites found in most vertebrate species and have been observed in close relation with ecology of birds (LÓPEZ et al., 2007). In addition to directly interfering with health, parasitism by coccidia in birds may interfere in the physiology (MARTINEZ-PADILLA, 2007) and behavior (AGUILAR, 2005; MASELLO et al., 2006). Depending on the coccidian species, the birds may be intermediate or definitive hosts and the symptoms may vary from inapparent infection to acute disease and in some cases ending in death. Adverse effects induced by coccidians or the costs associated with parasitism response may result in significant physiological and phenotypic costs potentially affecting the survival of nestlings in nests. In the parasite-host interaction, we can distinguish at least two steps: (1) the parasite must contact the host; (2) they must be adept at destroying them (MERINO, 2010). Immunity to coccidia develops depending on the number of oocysts ingested and this immunity does not prevent re-infection. In adult birds, a balance is reached between constant re-infection and the degree of immunity (KAWUTWALD - JUNGHANANS et al., 2009). Therefore, coccidiosis in wild birds in a habitat without environmental changes is rarely a significant problem; however, morbidity and mortality may occur when anthropic factors contribute to agglomerate and/or, mainly, to stress the birds (ATKINSON et al., 2008). 


\subsection{The project, its origin and integration}

The elaboration of this project originated from the interdisciplinary collaboration of Prof. Bruno Pereira Berto of the Laboratório de Biologia de Coccídios (LABICOC), Prof. Viviane Moreira de Lima of Laboratório de Atividade Genotóxica de Plantas (LAGeP) and Prof. Ildemar Ferreira of Laboratório de Ornitologia (LABOR), from Departamento de Biologia Animal (DBA), Instituto de Ciências Biológicas e da Saúde (ICBS), of Universidade Federal Rural do Rio de Janeiro (UFRRJ), and Prof. Sergio Thode-Filho, of Núcleo de Monitoramento Ambiental (NUMA) and Prof. Heider Alves Franco of Laboratório Multidisciplinar de Tecnologia AgroAmbiental (LAMTAA) from Instituto Federal de Educação, Ciência e Tecnologia do Rio de Janeiro (IFRJ).

The work of capture, record and collection of biological samples of wild birds for prevalence and identification of parasites developed by the Prof. Berto and Prof. Ferreira was initially associated to the work of identification and germination of forest seeds carried out by Prof. Thode-Filho and Prof. Franco. In this way, the seeds detected in fecal samples of wild birds could be identified and evaluated. In addition, the parasites and seeds are molecularly identified through the work of extraction, amplification and sequencing of the species carried out by Prof. Lima.

This project is also part of the Postdoctoral Prof. Thode-Filho at the Programa de Pós-graduação em Ciência, Tecnologia e Inovação em Agropecuária (PPGCTIA/UFRRJ), besides integrating the activities/projects of:

(1) Dra. Águida Aparecida de Oliveira (Laboratory Technician Doctor of the DBA/ICBS/UFRRJ);

(2) Mariana de Souza Oliveira (Doctoral student in the Programa de PósGraduação em Biologia Animal - PPGBA/UFRRJ);

(3) Lucas de Assis Silva Andrade (Doctoral student in the Programa de PósGraduação em Biologia Animal - PPGBA/UFRRJ); 
(4) Jhon Lennon Genovez de Oliveira (Master student in the Programa de PósGraduação em Biologia Animal - PPGBA/UFRRJ);

(5) Carla Maronezi (Veterinary Doctor recently graduated in the Centro Universitário de Barra Mansa);

(6) Carlos Nei Ortúzar Ferreira (Scientific Initiation Scholarship and graduating in Veterinary Medicine at UFRRJ);

(7) Saulo Tavares Abreu (Scientific Initiation Scholarship and graduating in Pharmacy at UFRRJ);

The primary site selected in this project was the IFRJ-Pinheiral campus, which has preserved, urbanized, cultivated and reforested areas, as well as a rich diversity of wild birds. These conditions made the IFRJ-Pinheiral campus representative for the initial development of this project, although it is being expanded to others locations in the Middle Paraíba region, to the Serrana region and to the Costa Verde coast of the State of Rio de Janeiro.

\section{METHODOLOGY}

\subsection{Capturing and collecting data and samples of wild birds}

At the capture locations, mist nets with different mesh sizes are used to capture birds of various sizes. The frequency of verification of the mist nets is 20 minutes, leading in sequence with manual removal of the bird, minimizing stress. The birds are specifically identified (SIGRIST, 2014), photographed, ringed with rings of the Centro Nacional de Pesquisa e Conservação de Aves Silvestres (CEMAVE), evaluated and recorded for the ecological, biological and biometric data (mass; temperature; total length; beak length, width and height; wing, tail and tarsal lengths; cranial pneumatization stage; accumulated fat content; incubation plate stage; primary wear stage) and verified and quantified for ectoparasites (ticks, mites and lice) (NASCIMENTO et al., 1994). Subsequently, the birds are kept in 
individual boxes with clean ground paper until defecation, when they are released at the same location of capture. Each fresh droplet of feces from each individual bird are placed in an individually centrifuge tube with a potassium dichromate $2.5 \%$ $\left(\mathrm{K}_{2} \mathrm{Cr}_{2} \mathrm{O}_{7}\right)$ solution. This methodology is authorized by the Instituto Brasileiro do Meio Ambiente e dos Recursos Naturais Renováveis (IBAMA) under authorization number 42798-1, by the Sistema Nacional de Anilhamento de Aves Silvestres (SNA) of CEMAVE under authorization number 4336-1 and by the Comissão de Ética no Uso de Animais do Instituto de Veterinária da Universidade Federal Rural do Rio de Janeiro (CEUA/UFRRJ) under authorization number 6606250616.

\subsection{Sample processing}

Fecal samples are transported in $15 \mathrm{ml}$ centrifuge tubes containing the ratio of $1 / 6$ feces to $5 / 6$ of $2.5 \% \mathrm{~K}_{2} \mathrm{Cr}_{2} \mathrm{O}_{7}$ solution. This conservator prioritizes the development and identification of coccidian oocysts, but also allows the conservation and identification of cysts of flagellate and ameboid protozoa and larvae and eggs of helminths. In order for the oocysts to remain viable the centrifuge tubes are periodically opened and homogenized ensuring a constant presence of atmospheric oxygen.

The parasites and plant seeds are separated from the solution containing feces and $\mathrm{K}_{2} \mathrm{Cr}_{2} \mathrm{O}_{7}$ by the modified technique of flotation with sucrose solution (500g sucrose, $350 \mathrm{ml}$ water) by centrifugation ( $5 \mathrm{~min}$ at $2000 \mathrm{rpm}$ ) described by Sheather (1923) and modified by Duszynski and Wilber (1997). The solution is suspended in distilled water in the centrifuge tubes repeatedly to remove excess $\mathrm{K}_{2} \mathrm{Cr}_{2} \mathrm{O}_{7}$. After this procedure, the material is suspended in sucrose solution and again centrifuged. After centrifugation, the contents of the centrifuge tube are raised with sucrose solution to the limit of the opening forming a converging 
meniscus, where a coverslip is deposited for 5 to $10 \mathrm{~min}$. After this period, the coverslip is removed and carefully placed on the surface of a microscope slide.

\subsection{Isolation and recovery of plant seeds}

Vegetable seeds are collected in two moments: (1) the larger and easily identified seeds are collected visually after defecation of the birds; (2) the smaller and less dense seeds than the sucrose solution float and can be easily removed with the aid of tweezers. Smaller seeds, but denser than the sucrose solution settle in the centrifuge tube and can be recovered at the end of the processing for quantification and identification.

\subsection{Identification of enteroparasites}

Optical microscopy in magnification of 400X and 1000X is used to improve the visualization and, consequently, greater detail and identification of the forms of oocysts, cysts, eggs and larvae of parasites (DE CARLI, 2007).

\subsection{Quantification of enteroparasites}

Quantification of eggs, larvae, cysts and/or oocysts is conducted according to Dolnik et al. (2010), where the totality recovered from a defecation is counted on a microscopy slide. To avoid counting errors, which may be caused by agglomeration of enteroparasites, all fields of the slide are observed. These results confer the density of one or mores parasites from a host (BUSH et al., 1997).

\subsection{Ecological study}

The statistical study consists of correlating the densities of the ectoparasites and enteroparasites with the ecological, biological and biometric data of the hosts 
and with the environmental conditions. The density results are submitted to log transformation prior to the application of ANOVA (SAMPAIO, 2002).

\subsection{Identification and evaluation of the vigor of forest seeds}

The identification of the seeds follow de guidelines of the Manual de Identificação e Cultivo de Plantas Arbóreas Nativas do Brasil (LORENZI, 2016). After identification, asepsis are employed leaving the seeds in sodium hypochlorite solution (2\%) for $5 \mathrm{~min}$ and then washing under running water. In the field, seeds are dried with filter paper with a temperature of approximately $30-35^{\circ} \mathrm{C}$ for $30 \mathrm{~min}$. For the Electrical Conductivity (EC) test are followed the recommendations proposed by Krzyzanowski et al. (1999), Flavio and Paula (2010), Guollo et al. (2017) and Thode-Filho (2018) with adaptations. Experiments are randomized with one treatment with five replicates. The tests are performed by the individual method (by seed) for 24 hours. The seeds are placed in individual plastic containers containing $15 \mathrm{~mL}$ of distilled water. Additionally, the EC is evaluated in five soak periods: 3, 6, 9, 12 and 24 hours. The parameters of the study are evaluated using a multiparameter probe AKSO Combo 5 and the results was expressed in $\mu \mathrm{S} \mathrm{cm}^{-1}$.

The data are submitted to analysis of variance (ANOVA) and the means are compared by the Tukey test (COSTA NETO, 1977; MILLER; MILLER, 1993).

\section{PRELIMINARY RESULTS}

To date, 196 wild birds have been captured (Figure 1A-G). Ectoparasitism has been frequently observed associated with feather mites, whereas ticks, lice and other ectoparasites have been less observed. Helminths, ciliates, amoebas and intestinal flagellates were not observed until the present moment in the samples. On the other hand, 42 of the 196 birds captured were infected by 20 different coccidian species, of which 14 species may be considered possible new species, 
since their morphology is not reported in the scientific literature. Among the coccidian species observed, the most frequent species belonged to the genus Isospora and, less frequently, species of Eimeria were identified (Figure $1 \mathrm{H}-\mathrm{I}$ ).

Figure 1 - Wild birds captured in reforestation area at the IFRJ Pinheiral Campus (A-G), and photomicrographs $(\mathrm{H}-\mathrm{I})$ of coccidian protozoa isolated from their fecal samples: Elaenia flavogaster (A); Thamnophilus caerulescens (B); Manacus manacus (C); Ramphocelus bresilius (D); Hylophilus thoracicus (E); Volatinia jacarina (F); Thlypopsis sordida (G); Eimeria sp. of $T$. caerulescens (1000x) (H); Isospora sp. of Trichothraupis melanops (1000x) (I)

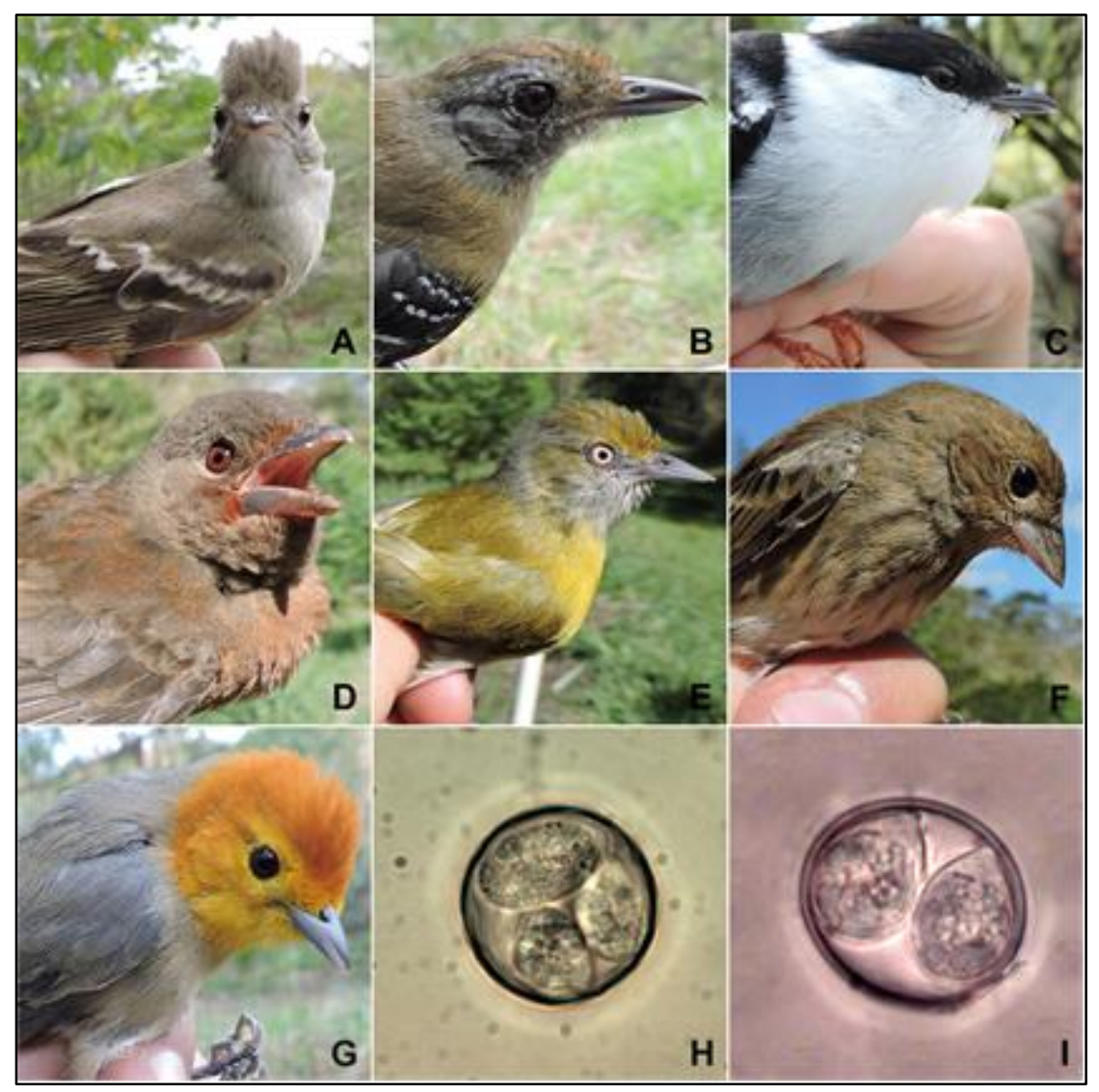

The predominance of parasitism has occurred in the Thraupidae family, both in number of species and in specimens. The main coccidian species observed in this family were: Isospora sepetibensis, Isospora ramphoceli, Isospora tiesangui, Isospora silvasouzai, Isospora sanhaci, Isospora coerebae, among other morphotypes 
not related in the literature and that are in the process of identification and description.

Preliminarily two scientific articles describing new coccidian species of gnateaters Conopophaga spp. and ruddy ground-dove Columbina talpacoti captured in the IFRJ-Pinheiral are in process of publication:

(1) SILVA-CARVALHO, L. M.; OLIVEIRA, J. L. G.; OLIVEIRA, M. S.; RODRIGUES, M. B.; ABREU, S. T.; ORTÚZAR-FERREIRA, C. N.; FRANCO, H. A.; THODE-FILHO, S.; OLIVEIRA, A. A.; LIMA, V. M.; FERREIRA, I.; BERTO, B. P. Isospora borbai n. sp. (Chromista: Miozoa: Eimeriidae) from gnateaters Conopophaga spp. (Passeriformes: Tyranni: Conopophagidae) in South America. Acta Parasitologica, 2019.

(2) ORTÚZAR-FERREIRA, C. N.; OLIVEIRA, M. S.; OLIVEIRA, J. L. G.; FRANCO, H. A.; THODE-FILHO, S.; OLIVEIRA, A. A.; LIMA, V. M.; FERREIRA, I.; BERTO, B. P. Coccidia of Columbiformes: A taxonomic review of its Eimeriidae species and Eimeria columbinae n. sp. from Columbina talpacoti (Temminck,1809) from Brazil. 2019.

As previously mentioned, the parasite-host relationship is common, not adversely affecting animal life and welfare. However, anthropic areas can generate stress in the animal, resulting in an immunological low and thus, increase the parasitic density and can then lead the animal to death. In any case, none of the birds captured to date did not show clinical signs of coccidiosis.

Ornithochory has been potentially observed in the samples obtained from birds in the IFRJ-Pinheiral. To date, seeds of 18 species have been identified from 6 families and 5 different species.

The identification and evaluation of the vigor of forest seeds has also been disseminated through two preliminary publications:

(1) THODE-FILHO, S.; FRANCO, H. A.; JORGE, E. N. L. F.; FERNANDES, M. S. FERREIRA, I.; BERTO, B. P. Evaluation of the electrical conductivity of forest seeds after digestive tract of wild birds. Ciência e Natura, v. 40, p. 79, 2018.

(2) THODE-FILHO, S.; FRANCO, H. A.; JORGE, E. N. L. F.; OLIVEIRA, M. S.; OLIVEIRA, J. L. G.; FERREIRA, I.; BERTO, B. P. Evaluation of the seed vigor of 
Tournefortia paniculata cham. post-digestive tract of the ruby-crowned tanager Tachyphonus coronatus (Vieillot, 1822). Ciência e Natura, 2019.

\section{TECHNICAL PRODUCTION}

Concomitantly with the research work of this project, there was concern about the dissemination and extension of activities and results. In this sense, two short courses have been developed in the field, at the IFRJ Pinheiral campus. The short courses were aimed to the technical high school students of the IFRJPinheiral, as well to the scientific community and society at large, being widely disseminated through physical and digital media. The short course held on September 6, 2018 was entitled: "Capture and Collection of Data and Samples of Wild Birds" (Figure 2); and the second short course held on February 27, 2019 was entitled "Capture, Management and Determination of Ornithocoric Potential of Wild Birds" (Figure 3). Both short courses involved a total of 70 participants (34 in September 2018 and 36 in March 2019) among IFRJ students, ornithologists and bird admirers, as well as local residents. In addition to this, a next short course is scheduled for August 2019, this time with a more theoretical approach.

Figure 2 - Short course (A-B) held on September 6, 2018, entitled "Capture and Collection of Data and Samples of Wild Birds", taught to IFRJ students, ornithologists and bird admirers, as well as local residents

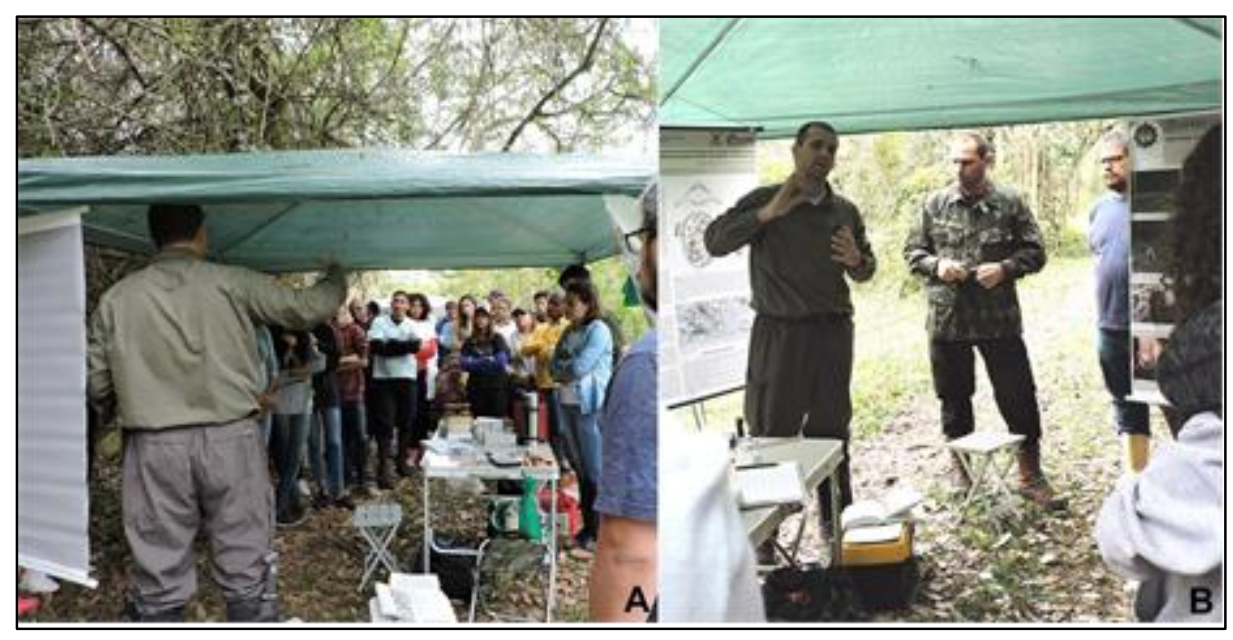

Ci. e Nat., Santa Maria, v.43, e13, 2021 
Figure 3 - Short course (A-B) held on February 27, 2019, entitled "Capture, Management and Determination of Ornithocoric Potential of Wild Birds" taught to IFRJ students, ornithologists and bird admirers, as well as local residents

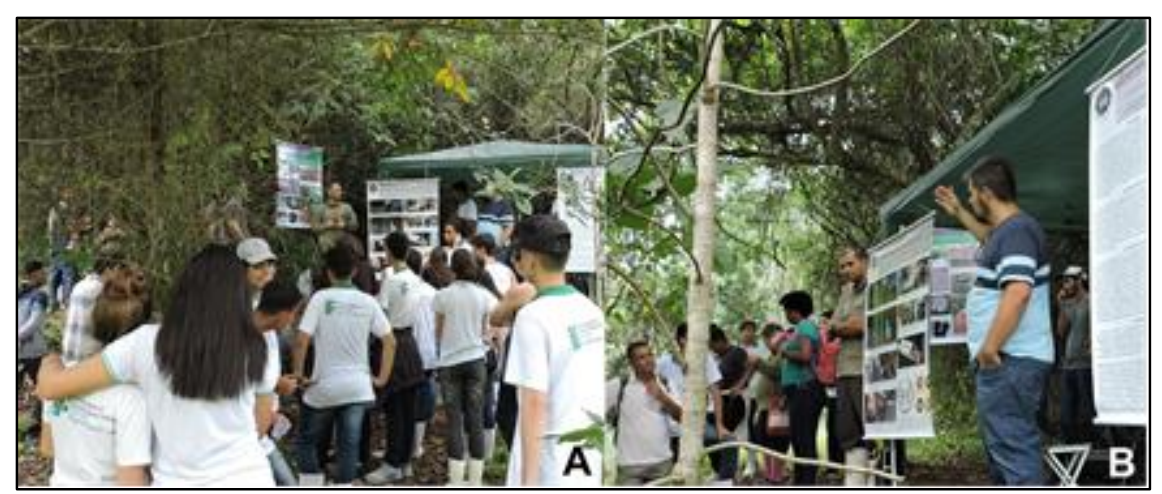

\section{ACKNOWLEDGMENT}

We are thankful to staff at the Instituto Federal de Educação, Ciência e Tecnologia do Rio de Janeiro (Campus Pinheiral), RJ, which allowed us to access and use some facilities during the expeditions and short courses. This study was supported by Coordenação de Aperfeiçoamento de Pessoal de Nível Superior (CAPES), Conselho Nacional de Desenvolvimento Científico e Tecnológico (CNPq), and Fundação Carlos Chagas Filho de Amparo à Pesquisa do Estado do Rio de Janeiro (FAPERJ).

\section{REFERENCES}

AGUILAR TM. Influência do parasitismo sobre a seleção sexual e avaliação de parâmetros de hábitat sobre o sucesso reprodutivo de Volatinia jacarina (AVES: PASSERIFORMES, EMBERIZIDAE). [Tese]. Brasília: Universidade de Brasília/UNB; 2005.

ANTONINI RD. Frugivory and seed dispersal by birds at two species of Miconia (Melastomataceae) in an atlantic Forest área at Ilha da Marambaia, RJ. [Dissrtation]. Seropédica: Universidade Federal Rural do Rio de Janeiro/UFRRJ; 2007.

BARBOSA FBC. The Biotechnology and the Amazonia biodiversity conservation, its impact on environmental policies. Cadernos de Ciência \& Tecnologia, Brasília, 2001. 18(2). p.69-94. 
BERTO BP, LOPES CWG. Distribution and dispersion of coccidia in wild 542 passerines of the Americas. In RUIZ L and IGLESIAS F. Birds: evolution and behavior, breeding strategies, migration and spread of disease. New York: Nova Science Publishers, 2013.p. 47-66.

BIZERRIL MXA. O estudo da frugivoria e da dispersão de sementes: qual a sua importância e o que investigar? Universitas. Biociências. 2000;1(1):69-80.

BREVES, R. San `tana do Piraí e a sua história. Rio de Janeiro: Daiadorin Editora. 258 p, 1994.

BUSH, A.O. et al. Parasitology Meets Ecology on Its Own Terms- Margolis et al. Revisited. J. Parasitol. 1997;83:575-583.

CARVALHO-FILHO PR, MEIRELES GS, RIBEIRO CT, LOPES CWG. Three new species of Isospora Schneider, 1881 (Apicomplexa: Eimeriidae) from the double-collared seed eater, Sporophila caerulescens (Passeriformes: Emberizidae), from Eastern Brazil. Mem. Inst. Oswaldo Cruz. 2005; 100(02):151-154.

COSTA NETO, P. L. O. Estatística. São Paulo: Edgard Blücher, 1977. 264 p.

DE CARLI GA. Exames Macroscópico e Microscópico da Amostra Fecal Fresca e Preservada. In: GA De Carli (ed) Parasitologia Clínica-Seleção de Métodos e Técnicas de Laboratório para o Diagnóstico das Parasitoses Humanas, $2^{\mathrm{a}}$ ed. Atheneu. São Paulo, 2007.

DOLNIK OV, DOLNIK VR, BAIRLEN F. The effect of host foraging ecology on the prevalence and intensity of coccidian infection in wild passerine birds. Ardea. 2010;98(1):97-103.

DUSZYNSKI DW, WILBER PG. A guideline for the preparation of species descriptions in the Eimeridae. J. Parasitol. 1997:83(2):333-336.

FLAVIO JJP, PAULA RC. Testes de envelhecimento acelerado e de condutividade elétrica em sementes de Dictyoloma vandellianum A. Juss. Sci. For. 2010;38(87):391-399.

FUNDAÇÃO INSTITUTO ESTADUAL DE FLORESTAS- IEF. A Mata Atlântica no Estado do Rio de Janeiro. Cited:[2019 jul 11]. Available from: http://www.ief.rj.gov.br/mata/conteudo.hmt.

FUNDAÇÃO SOS MATA ATLÂNTICA \& INSTITUTO NACIONAL DE PESQUISAS ESPACIAIS. Atlas dos remanescentes florestais da Mata Atlântica: Período 1995-2000. São Paulo, 2002. 47p.

FRANCISCO MR, GALETTI M. Frugivoria e dispersão de sementes de Rapanea lancifolia (Myrsinaceae) por aves numa área de cerrado do estado de São Paulo, sudeste do Brasil. Ararajuba. 2002;9(1):13-19.

FREITAS MFL, OLIVEIRA AB, CAVALCANTI MDB, LEITE AS. Parasitos gastrointestinales de aves silvestres em cautiveiro em el estado de Pernambuco, Brasil. Parasitol. Latinoam. 2002;57:5054. 
GUOLLO K, POSSENTI JC, FELIPPI M, DEL QUIQUI EM, DEBASTIANI AB. Avaliação da Qualidade Fisiológica de Sementes Florestais através do Teste de Condutividade Elétrica. Sci. Agrar. 2017;16:374-382.

IFRJ - INSTITUTO FEDERAL DE EDUCAÇÃO, CIÊNCIA E TECNOLOGIA DO RIO DE JANEIRO. Campus Pinheiral. Cited [2019 jul 11]. Available from: portal.ifrj.edu.br/pinheiral.

JANZEN DH. Herbivores and the number of tree species in tropical florest. Am. Natural. 1910;104:501-528.

KRZYZANOWSKI FC, VIEIRA RD, FRANCA NETO JB. Vigor de sementes: conceitos e testes. Londrina: Abrates; 1999.

LÓPEZ G, FIGUEROLA J, SORIGUER R. Time of day, age and feeding habits influence coccidian oocyst shedding in wild passerines. Int. J. Parasitol. 2007;37:559-564.

LORD JM, NORTON DA. Scale and the Spatial Concept of Fragmentation. Conservation Biology. 1990;4(2):197-202.

MARTINEZ-PADILLA J, MILLÁN J. Prevalence and intensity of intestinal parasitation in a wild population of nestling Eurasian kestrel Falco tinnunculus. Ardeola. 2007; 54(1), 109-115.

MARTINS ICM, SOARES VP, SILVA E, BRITES RS. Diagnóstico ambiental no contexto da paisagem de fragmentos florestais naturais "ipucas" - no Município de Lagoa da Confusão-Tocantins. R. Árvore. 2002;26(3):299-309.

MASELLO JF, CHOCONI RG, SEHGAL RNM, TELL L, QUILLFELDT P. Blood and intestinal parasites in wild Psittaciformes: a case study of burrowing parrots (Cyanoliseus patagonus). Ornitol. Neotrop.. 2006;17(4) 515-520.

MILLERJC, MILLER, JN. Statistics for Analytical Chemistry, New York: Ellis Horwood Limited; 1993. MYERS N, MITTERMEIER RA, MITTERMEIER CG, FONSECA GAB, KENT J. Biodiversity hotspots for conservation priorities. Nature. 2000;403:53-858.

NASCIMENTO M. T. A monodominant rain forest on Maracá Island, Roraima, Brazil: forest structure and dynamics, 1994.

PEREIRA CC, SOARES FS, FONSECA RS, NETO SD. Frugivoria e dispersão por aves das sementes de Erythroxylum suberosum A.St.-Hil. (Erythroxylaceae) no cerrado brasileiro. Atualidades Ornitológicas. 2014;182:18-20.

SAMPAIO IBM. Estatística aplicada à experimentação animal. Belo Horizonte: FEPMVZ.2002. 
SARAVY FP, FREITAS PJD, LAGE MA, LEITE SJ, BRAGA LF, SOUSA MP. Síndrome de dispersão em estratos arbóreos em um fragmento de floresta ombrófila aberta e densa em Alta Floresta MT. Revista do Programa de Ciências Agro-Ambientais. 2003;2(1):1-12.

IGRIST T. Guia de Campo: Avifauna Brasileira. São Paulo: Avis Brasilis; 2014.

SHEATHER, A. L. The detection of intestinal protozoa and mange parasites by a flotation technique. J. Comp. Pathol. 1923;36:266-275.

SILVA MR. A formação do Técnico em Agropecuária do Colégio Agrícola Nilo Peçanha - CANP/RJ: Um estudo de caso sobre a interface com a agroecologia [dissertation]. Seropédica: Universidade Federal Rural do Rio de Janeiro/UFRRJ; 2009. 114p.

SILVEIRA CS, SILVA VV. Dinâmica de regeneração e desmatamento da vegetação provocadas por fatores climáticos e geomorfológicos: uma análise geoecológica através de SIG. R. Árvore. 2010;34(6):1025-1034.

THODE FILHO S, FRANCO HA, de LIMA FIGUEIREDO ENN, DA SILVA FERNANDES M, FERREIRA I, BERTO BP. Evaluation of the electrical conductivity of forest seeds after digestive tract of wild birds. Ciênc. Nat. 2018;v.40;e79.

VENTUROLI F, FELFILI JM, FAGG CW. Avaliação temporal da regeneração natural em uma Floresta Estacional Semidecídua Secundária, em Pirenópolis, Goiás. R. Árvore. 2001;35(3):473483.

\section{Authorship contributions}

\section{1 - Sérgio Thode-Filho}

Doctor of Science, http://orcid.org/0000-0001-7930-8312 e sergio.thode@ifrj.edu.br Contribuição: Conceptualization, Methodology, Data analysis, and Writing-Original draft preparation.

\section{2 - Heider Alves Franco}

Doctor of Science https://orcid.org/0000-0002-8574-5049 e heider.franco@ifrj.edu.br Contribuição: Conceptualization and Supervision

\section{3 - Emanuele Nunes de Lima Figueiredo Jorge}

Master of Technology https://orcid.org/0000-0002-6766-6072 e emanuele.jorge@ifrj.edu.br Contribuição: Conceptualization and Supervision 


\section{4 - Mariana de Souza Oliveira}

Master of Science

https://orcid.org/0000-0001-9594-0633 e mariana.s.o@hotmail.com

Contribuição: Methodology, Data analysis, and Writing-Original draft preparation

\section{5 - Jhon Lennon Genovez-Oliveira}

Titulação Master of Science

http://orcid.org/0000-0003-2994-397X e jhonlennon_usher@hotmail.com

Contribuição: Methodology and Data analysis.

\section{6 - Lucas de Assis Silva Andrade}

Master of Science

https://orcid.org/0000-0001-8203-9299 e lucasandrade.as@hotmail.com

Contribuição: Methodology and Data analysis

\section{7 - Carlos Nei Ortúzar-Ferreira}

Veterinary Graduate

https://orcid.org/0000-0002-0177-5591 e carlosneiortuzarferreira5@hotmail.com

Contribuição: Methodology and Data analysis

\section{8 - Saulo Tavares Abreu}

Pharmacy Graduate

https://orcid.org/0000-0001-6702-6983 e abreu.saulo.st@gmail.com

Contribuição: Methodology and Data analysis

\section{9 - Carla Maronezi}

Veterinary Graduate https://orcid.org/0000-0002-6704-0395 e maronezi.carla@gmail.com Contribuição: Methodology and Data analysis

\section{0 - Águida Aparecida de Oliveira}

Doctor of Science

http://orcid.org/0000-0001-8685-0345 e aguidaoliveira@gmail.com

Contribuição: Supervision

\section{1 - Viviane Moreira de Lima}

\section{Doctor of Science}

http://orcid.org/0000-0001-7930-8312 e vilima@hotmail.com

Contribuição: Supervision

\section{2 - Ildemar Ferreira}

Doctor of Science https://orcid.org/0000-0002-6128-5789 e ferreira@ufrrj.br Contribuição: Supervision 
20 | Parasitic density and ornithochoric potential of wild birds: Preliminary results of a research...

\section{3 - Bruno Pereira Berto}

Doctor of Science

http://orcid.org/0000-0002-1072-5254 e berto.ufrrj@gmail.com

Contribuição: Conceptualization, Supervision, Reviewing and Editing 